\title{
Antimicrobial Activity and Mineral Composition of Shiitake Mushrooms Cultivated on Agricultural Waste
}

\author{
Kérley Braga Pereira Bento Casaril ${ }^{1 *}$, Maria Catarina Megumi Kasuya ${ }^{2}$ and Maria \\ Cristina Dantas Vanetti ${ }^{2}$ \\ ${ }^{1}$ Departamento de Economia Doméstica; Universidade Estadual do Oeste do Paraná; Rua Maringá, 1200; \\ Francisco Beltrão - PR - Brasil. ${ }^{2}$ Departamento de Microbiologia; Universidade Federal de Viçosa; Av. P. H. \\ Rolfs. s/n; Viçosa - MG - Brasil
}

\begin{abstract}
The antimicrobial activity and mineral composition of shiitake mushrooms were evaluated in four isolates of Lentinula edodes. Mushrooms were cultivated on artificial logs, based on eucalyptus sawdust enriched with $20 \%$ rice, wheat, or soybean bran, or combination of $10 \%$ of two of these supplements. The substrates were humidified with a $0.1 \%$ mate tea extract or water. Logs of Eucalyptus grandis were also used to cultivate the shiitake mushrooms. The antimicrobial activity of an aqueous extract, corresponding to $40 \mathrm{mg}$ of mushroom dry matter, was in some cases, depending on the isolate, able to inhibit both Bacillus subtilis and Escherichia coli $K$-12, independent of substrate composition or the growth stage of the mushrooms. Nitrogen, phosphorus, potassium, magnesium and calcium concentrations varied according to the substrate on which the mushrooms were cultivated, being, generally, higher with cultivation on artificial rather than natural eucalyptus logs. It could be concluded that, in addition to the fungal isolate, substrate composition and, processing methods must be considered during the production of antimicrobial substance(s) as well as in the mushroom nutritional composition
\end{abstract}

Key words: Antibacterial property, Lentinula edodes, mineral nutrients, sawdust-based substrate, mushrooms

\section{INTRODUCTION}

Lentinula edodes (Berk.) Pegler, commonly known as shiitake mushroom, is the second most important cultivated edible mushroom in the world (Royse, 2001). It is a wood-decaying white-rot fungus that naturally inhabits the dead wood of many hardwood tree species under various climatic conditions (Przbylowicz and Donogue, 1990; Ohga, 1992). Traditionally, shiitake has been cultivated outdoors on the hardwood logs of oak, nuts or eucalyptus (Mata and Savoie, 1998).
Alternatively, indoor cultivation techniques using sawdust-based substrates in plastic bags have been developed (Ohga, 1992). Sawdust is the most popular basal ingredient used in the synthetic formulations for producing shiitake, but other basal ingredients may include straw, corncobs, or both (Ohga, 1992; Royse, 2001). Regardless of the main ingredient, starch-based supplements such as wheat bran, rice bran, soybean bran, millet, rye or corn, can be added to the mix (Royse, 2001; Royse and Sanchez, 2007; Regina et al., 2008). Shiitake cultivation in plastic bags reduces the production

*Author for correspondence: kcasaril@gmail.com 
time, increases the production efficiency, and allows for year-round shiitake production (Ohga, 1992; Royse, 2001; Campbell and Racjan, 1999).

Whether grown on logs or sawdust-based substrates, L. edodes has been shown to produce a variety of degradative extracellular enzymes, including cellulases, hemicellulases, fungal cell wall-degrading enzymes, acid phosphatases, acid proteinases, laccases, manganese peroxidases, and ligninases that contribute to the degradation and recycling of wood in nature (Savoie et al., 1998; Ohga and Royse, 2001; Makkar et al., 2001; Hatvani and Mécs, 2001; Hatvani and Mécs, 2002; Nagai et al., 2002; Nagai et al., 2003; Silva et al., 2005; Silva et al., 2008; Regina et al., 2008).

Shiitake has interested researchers due to its medicinal properties, and several biologically active compounds have been isolated and purified from the mushrooms, mycelia and aqueous extract (Chang, 1999; Ishikawa et al., 2001; Hassegawa et al., 2005). These compounds exhibit antitumoral, antifungal, antibacterial, hypoglycemic and antioxidant properties (Maeda et al., 1998; Ngai and Ng, 2003; Ishikawa et al., 2001; Yang et al., 2002; Kitzberger et al., 2007) that can have one or more therapeutic effects and can act synergistically (Pascholati et al., 1998; Wasser and Weis, 1999). Among these compounds, some of the best characterized are lentinan (Chihara et al., 1969; Minato et al., 1999), KS-2, (Fujii et al., 1978), lentinacin (2(R), 3(R)-dihidrixi-4-(9 adenil)- butyric acid), known as eritadenine (Shimada et al., 2003a; Shimada et al., 2003b, Enman et al., 2008), and fruit body protein (FBP), which inhibits the tobacco mosaic virus (Kobayashi et al., 1987. Lentinamycin (octa-2, 3diene-5, 7-diyne-1-ol) was isolated and purified from a liquid culture of $L$. edodes (Bew et al., 1966). This compound inhibits the growth of Trichoderma sp (Tokimoto et al., 1987) and Grampositive bacteria (Komemushi et al., 1996). The antimicrobial activity of $L$. edodes has been confirmed against the Gram-positive and Gramnegative bacteria, filamentous fungi, yeast and viruses (Chihara et al., 1969; Komemushi et al., 1995; Hirasawa et al., 1999; Pacumbaba et al. 1999; Sasaki et al., 2001; Hatvani, 2001; Ishikawa et al., 2001; Hassegawa et al., 2005).

There is some evidence that substrate composition can influence the chemical composition of the mushrooms (Manzi et al., 1999), but little is known about its nutritional value (Vetter, 1994). The aim of the present study was to investigate the influence of substrate composition on both mineral composition and antimicrobial activity in the fresh or dried mushrooms, harvested at different growth stages.

\section{MATERIALS AND METHODS}

\section{Microorganisms}

Four isolates of L. edodes, UFV11 (Le1), UFV52, UFV62 and UFV63 from the culture collection of the Department of Microbiology at the Federal University of Viçosa (MG), Brazil, were selected for this study due to their antimicrobial activity and growth observed in previous studies (Ishikawa et al., 2001; Hassegawa et al., 2005). Culture stocks were kept in the tubes with malt extract agar plus peptone ( $30 \mathrm{~g}$ malt extract, $3 \mathrm{~g}$ soybean peptone, $15 \mathrm{~g}$ agar, and the extract of mate tea $1 \%$, $\mathrm{pH}$ 4.5). The isolates were grown on malt extract agar plus peptone in $90 \mathrm{~mm}$ Petri dishes at $25^{\circ} \mathrm{C}$. Bacillus subtilis and Escherichia coli $\mathrm{K}-12$ were selected as the representative Gram-positive and Gram-negative groups of bacteria, respectively. These isolates were obtained from the culture collection of the Food Microbiology Laboratory at the Federal University of Viçosa (MG), Brazil. The stock cultures were maintained on Brain Heart Infusion (BHI, Merck) slants at $4^{\circ} \mathrm{C}$. The isolates were grown aerobically in $\mathrm{BHI}$ at $37^{\circ} \mathrm{C}$.

\section{Growth of shiitake mushrooms on sawdust-} based substrates with different compositions Isolates UFV11, UFV52 and UFV63 of L. edodes were used to produce the shiitake mushrooms on sawdust-based substrates. Initially, the sawdust was humidified with water, or $0.1 \%$ mate tea extract. After $24 \mathrm{~h}$, the excess water or mate tea was drained, and the sawdust was enriched with following: $20 \%$ rice bran (RB), $20 \%$ soybean bran (SB), $20 \%$ wheat bran (WB), 10\% RB $+10 \% \mathrm{SB}$, $10 \% \mathrm{RB}+10 \% \mathrm{WB}$, or $10 \% \mathrm{SB}+10 \% \mathrm{WB}$. Polyethylene bags were filled with $600 \mathrm{~g}$ (wet wt). sawdust-based substrate. The substrates were pasteurized by heating at $100^{\circ} \mathrm{C}$ for $8 \mathrm{~h}$ and allowed to cool at room temperature. Next, they were inoculated with each fungal isolate by cutting the isolate from the margins of young colonies from 15-day-old cultures, resulting in five discs of $7 \mathrm{~mm}$ in diameter. The substrates were incubated at room temperature until mycelia developed throughout. Fruiting body primordia formation was stimulated 90 days after the inoculation by 
incubating the fungi at $10^{\circ} \mathrm{C}$ for 2 days. The blocks were then immersed in water at $15^{\circ} \mathrm{C}$ for $6 \mathrm{~h}$. The fruit bodies were harvested after 5 days while the hat was still closed (Table 1). The mushrooms were taken to the laboratory and a portion was dried at $40^{\circ} \mathrm{C}$ for $72 \mathrm{~h}$, packed in plastic bags and stored at room temperature. Fresh mushrooms were packed in polyethylene bags and stored at $5^{\circ} \mathrm{C}$. Mushrooms that produced more than $20 \mathrm{~g}$ per sawdust-based substrate were used for determining the antimicrobial activity. The experiment was conducted with 15 replicates and repeated twice.

\section{Growth of shiitake mushrooms on eucalyptus $\log$}

The logs of Eucalyptus grandis $(20-25 \mathrm{~cm}$ diameter, $100 \mathrm{~cm}$ long) were inoculated with $L$. edodes isolates UFV52, UFV62 or UFV63 as suggested by Przbylowicz and Donogue (1990). The logs were kept stacked and covered in a greenhouse and moistened every day. Every 30 days, the piles were turned to ensure that the fungal growth was uniform. After 90 to 120 days, as the mushroom primordial began to grow and induced uniform mushroom formation, bed logs were soaked in fresh, cool water for $12 \mathrm{~h}$ to stimulate the fruiting. Fruiting bodies were harvested 3, 5 and 8 days after the fructification induction and taken to the laboratory. Part of the samples was dried at $40^{\circ} \mathrm{C}$ for $72 \mathrm{~h}$, packed in plastic bags and stored at room temperature. Fresh mushrooms were packed in polyethylene bags and stored at $-5^{\circ} \mathrm{C}$.

\section{Antimicrobial substance(s) from shiitake mushrooms}

The antimicrobial activity of $L$. edodes was evaluated in the fresh fruit bodies. Fresh mushrooms $(50 \mathrm{~g})$ were immersed in $100 \mathrm{~mL}$ distilled water and ground in a mixer. After fragmentation, $100 \mathrm{~mL}$ of $90 \%$ methanol was mixed with the mushrooms and the mixture was maintained at room temperature for $24 \mathrm{~h}$. The mixture was then filtered using filter paper. The material left in the filter paper was dried at $60^{\circ} \mathrm{C}$ for dry-matter determination. Methanol was evaporated at $40^{\circ} \mathrm{C}$. The aqueous supernatant was concentrated to $50 \mathrm{~mL}$ and then mixed by vigorously shaking with $50 \mathrm{~mL}$ ethyl acetate three times. The organic layer was separated and evaporated to yield a light yellow material ethyl acetate extract. The aqueous extract was concentrated to $20 \mathrm{~mL}$ and filter sterilized using a $0.45 \mu \mathrm{m}$ pore size-membrane (Hirasawa et al., 1999).

\section{Antimicrobial activity of the aqueous extract}

The antimicrobial activity of the aqueous extract was assayed using an ELISA test. A microplate was washed in a solution of $200 \mathrm{mg} \mathrm{mL}^{-1}$ sodium hypochlorite and left under ultra-violet light for 20 min. For each spot, $60 \mu \mathrm{L}$ of the aqueous extract filtered from the mushroom was added, the equivalent to $40 \mathrm{mg}$ of dry mushroom, along with $180 \mu \mathrm{L}$ BHI broth. The mixture was inoculated with $10 \mu \mathrm{L}$ of $10^{5} \mathrm{CFU}$ per $\mathrm{mL}^{-1}$ of an active culture of $B$. subtilis or E. coli. The ELISA microplates were incubated at $37^{\circ} \mathrm{C}$ and bacterial growth was determined by measuring the optical density (OD) at $560 \mathrm{~nm}$ in Multiskan Plus Version 2.01 (Plow Laboratories, McLean, VA) microplate reader for $12 \mathrm{~h}$ at two-hour intervals. As positive controls, cultures of B. subtilis and E. coli grown in BHI broth were used, and BHI broth was used as a negative control. The experiment was conducted in triplicate and repeated three times. The data were submitted to ANOVA and standard variations were calculated.

\section{Nutrient concentration in shiitake mushroom}

Nutrient concentration was assayed in the shiitake dry-matter isolates UFV52, UFV62 and UFV63 after trituration and extraction of the antimicrobial substances. Nutrient concentration was also assayed in the dried mushrooms of isolates UFV52 and UFV63. Phosphorus, potassium, magnesium and calcium concentrations were determined by nitropercloric digestion after dry-ashing of samples (Tedesco et al., 1995). Phosphorus concentration was determined using a colorimetric method (Braga and Defilipo, 1974). K, Mg and Ca concentrations were determined using an atomic absorption spectrophotometer. Nitrogen concentration was determined after dry-ashing the samples with $\mathrm{H}_{2} \mathrm{SO}_{4}$, by using a colorimetric spectrophotometer by measuring the optical density (OD) at $625 \mathrm{~nm}$ (Cataldo et al., 1974). The analyses were done in duplicates two times. Data were submitted to ANOVA and media were compared via the Scott-Knott test $(\mathrm{P}<0.05)$ (Table 1 and 2). 
Table 1 - Condition of production and processing of shiitake mushrooms, isolates UFV52 and UFV63, cultivated on sawdust-based substrate, collected 5 days after fructification induction and extraction of antimicrobial substances, fresh or dried.

\begin{tabular}{|c|c|c|c|c|}
\hline Treatment & Isolate & Water/Mate tea & Substrate & Fresh/dried \\
\hline S1 & UFV52 & Water & $\mathrm{S}+\mathrm{WB}$ & Fresh \\
\hline $\mathrm{S} 2$ & UFV63 & Water & $\mathrm{S}+\mathrm{WB}$ & Fresh \\
\hline S3 & UFV63 & Water & $\mathrm{S}+\mathrm{RB}$ & Fresh \\
\hline S4 & UFV52 & Water & $\mathrm{S}+\mathrm{RB}+\mathrm{SB}$ & Fresh \\
\hline S5 & UFV63 & Water & $\mathrm{S}+\mathrm{RB}+\mathrm{SB}$ & Fresh \\
\hline S6 & UFV52 & Water & $\mathrm{S}+\mathrm{RB}+\mathrm{WB}$ & Fresh \\
\hline S7 & UFV63 & Water & $\mathrm{S}+\mathrm{RB}+\mathrm{WB}$ & Fresh \\
\hline S8 & UFV52 & Mate Tea & $\mathrm{S}+\mathrm{RB}+\mathrm{SB}$ & Fresh \\
\hline S9 & UFV63 & Mate Tea & $\mathrm{S}+\mathrm{RB}+\mathrm{SB}$ & Fresh \\
\hline S10 & UFV52 & Mate Tea & $\mathrm{S}+\mathrm{RB}+\mathrm{WB}$ & Fresh \\
\hline S11 & UFV63 & Mate Tea & $\mathrm{S}+\mathrm{RB}$ & Fresh \\
\hline S12 & UFV52 & Mate Tea & $\mathrm{S}+\mathrm{RB}$ & Fresh \\
\hline S13 & UFV63 & Mate Tea & $\mathrm{S}+\mathrm{FT}$ & Fresh \\
\hline S14 & UFV63 & Mate Tea & $\mathrm{S}+\mathrm{SB}+\mathrm{WB}$ & Fresh \\
\hline S15 & UFV63 & Water & $\mathrm{S}+\mathrm{WB}$ & Dried \\
\hline S16 & UFV63 & Mate Tea & $\mathrm{S}+\mathrm{WB}$ & Dried \\
\hline
\end{tabular}

$\mathrm{S}=$ Sawdust-based substrate, $\mathrm{RB}=$ Bran of Rice, $\mathrm{SB}=\mathrm{Bran}$ of Soybean and $\mathrm{WB}=\mathrm{Bran}$ of Wheat.

Table 2 - Conditions of production and processing of shiitake mushrooms, isolates UFV52, UFV62 and UFV63, cultivated on eucalypt logs (L), and collected in different growth stages after fructification induction and extraction of antimicrobial substances, fresh or dried.

\begin{tabular}{lccc}
\hline Treatment & Growth stages & Isolate & Fresh/Dried \\
\hline L1 & 5 days & UFV63 & Fresh \\
L2 & 5 days & UFV52 & Fresh \\
L3 & 3 days & UFV52 & Fresh \\
L4 & 5 days & UFV52 & Fresh \\
L5 & 8 days & UFV52 & Fresh \\
L6 & 3 days & UFV63 & Fresh \\
L7 & 5 days & UFV63 & Fresh \\
L8 & 8 days & UFV63 & Fresh \\
L9 & 5 days & UFV62 & Fresh \\
L10 & UFV52 & Dried \\
L11 & days & UFV62 & Dried \\
L12 & UFV63 & Dried \\
L13 & 5 days & UFV52 & Dried \\
L14 & 5 days & UFV63 & Dried \\
\hline
\end{tabular}

\section{RESULTS}

Fructification of shiitake mushrooms on sawdust and eucalyptus logs

Differences in the mycelial growth among isolates UFV11, UFV52 and UFV63 were observed in the substrates enriched with rice, soybean or wheat bran. Poor mycelial growth was observed in the substrates enriched with $20 \% \mathrm{SB}$, humidified with either mate tea extract, or water, and this resulted in less mushroom production (Table 3). Although isolate UFV11 presented good mycelial growth, almost no fructification was observed (Table 3 ).
This showed that visible vigorous mycelial growth did not reflect high mushroom production.

Isolate UFV52 presented intense mycelial growth on almost all the substrates. Higher production could be seen mainly on those substrates that were enriched with $20 \%$ WB humidified with water and $10 \% \mathrm{RB}+10 \% \mathrm{SB}$ and $10 \% \mathrm{RB}+10 \% \mathrm{WB}$, humidified with mate tea (Table 3). Colonization of the substrates by L. edodes UFV63 was slower than UFV52 and the former presented fructification on all the substrates (Table 3), except the substrate with $10 \% \mathrm{RB}+10 \%$ WB humidified with mate tea. 
Table 3 - Production (g) of shiitake mushrooms cultivated on sawdust-based substrates humidified with water (WW) or $0.1 \%$ mate tea extract (MT), and enriched with $20 \%$ rice (RB), soybean (SB), wheat (WB) bran or combination of $10 \%$ of two of these supplements.

\begin{tabular}{|c|c|c|c|c|c|c|c|}
\hline Substrate & WW/MT & Strain & Production (g) & Substrate & WW/MT & Strain & Production (g) \\
\hline \multirow{6}{*}{$\mathrm{RB}$} & & UFV 11 & 0 & \multirow{6}{*}{$\mathrm{RB}+\mathrm{SB}$} & \multirow{3}{*}{ WW } & UFV 11 & 0 \\
\hline & WW & UFV 52 & 1.54 & & & UFV 52 & 12.95 \\
\hline & & UFV 63 & 52.87 & & & UFV 63 & 29.91 \\
\hline & \multirow{3}{*}{ MT } & UFV 11 & 0 & & \multirow{3}{*}{ MT } & UFV 11 & 2.82 \\
\hline & & UFV 52 & 7.94 & & & UFV 52 & 66.10 \\
\hline & & UFV 63 & 26.72 & & & UFV 63 & 48.78 \\
\hline \multirow{6}{*}{ SB } & \multirow{3}{*}{ WW } & UFV 11 & 0 & & \multirow{3}{*}{ WW } & UFV 11 & 0 \\
\hline & & UFV 52 & 7.50 & & & UFV 52 & 12.63 \\
\hline & & UFV 63 & 6.07 & $\mathrm{RB}+\mathrm{WB}$ & & UFV 63 & 45.96 \\
\hline & \multirow{3}{*}{ MT } & UFV 11 & 0 & & \multirow{3}{*}{ MT } & UFV 11 & 20.62 \\
\hline & & UFV 52 & 0 & & & UFV 52 & 36.26 \\
\hline & & UFV 63 & 0.65 & & & UFV 63 & 0 \\
\hline \multirow{6}{*}{ WB } & \multirow{3}{*}{ WW } & UFV 11 & 3.15 & & \multirow{3}{*}{ WW } & UFV 11 & 0 \\
\hline & & UFV 52 & 51.57 & & & UFV 52 & 0 \\
\hline & & UFV 63 & 76.57 & $\mathrm{SB}+\mathrm{WB}$ & & UFV 63 & 4.54 \\
\hline & \multirow{3}{*}{ MT } & UFV 11 & 0 & & \multirow{3}{*}{ MT } & UFV 11 & 0 \\
\hline & & UFV 52 & 9.23 & & & UFV 52 & 5.73 \\
\hline & & UFV 63 & 13.82 & & & UFV 63 & 13.63 \\
\hline
\end{tabular}

The average productivity of mushrooms on the eucalyptus logs varied according to $L$. edodes strain. Strain UFV52 had the highest and fastest fructification, producing mushrooms 90 days after inoculation, while isolates UFV62 and UFV63 began to frutify after 120 days. These strains produced mushrooms with different morphological characteristics. UFV52 mushrooms were bigger and had little pigment, while UFV62 and UFV63 isolates were smaller and darker (data not shown).

\section{Antimicrobial activity of the aqueous extract}

The wastes used as substrates for shiitake mushroom production influenced the production of antimicrobial substance(s) by the isolates UFV52 and UFV63. The aqueous extract from the isolate UFV52 cultivated on sawdust-based substrate enriched with bran inhibited the growth of both $B$. subtilis and E. coli, and substrates moistened with $0.1 \%$ mate tea extract generally showed higher antimicrobial activity (Fig. 1). There was no growth of $B$. subtilis or $E$. coli in the presence of the aqueous extract of isolate UFV52 cultivated on sawdust enriched with $10 \% \mathrm{RB}+10 \% \mathrm{SB}$ when the compost was humidified with water. The aqueous extract of the isolate UFV52 cultivated in the sawdust enriched with $10 \% \mathrm{RB}+10 \% \mathrm{WB}$ showed antimicrobial activity against $B$. subtilis and E. coli (Fig. $1-\mathrm{A} 2$ and B2). The aqueous extract from the isolate UFV52 cultivated on sawdust-based substrate enriched with $20 \%$ RB and humidified with mate tea inhibited the growth of E. coli (Fig. 1 - B2).

The extracts from fresh mushrooms of isolate UFV63 inhibited the growth of both $B$. subtilis and E. coli (Fig. 2). The aqueous extract from the isolate UFV63, cultivated on sawdust-based substrate enriched with $10 \% \mathrm{RB}+10 \% \mathrm{SB}$ inhibited the growth of $B$. subtilis when the compost was humidified with water or mate tea and the growth of $E$. coli when the compost was humidified with mate tea (Fig. 2). The was no growth of $B$. subtilis in the presence of the aqueous extract of the isolate UFV63 cultivated on sawdust enriched with $10 \% \mathrm{WB}+10 \% \mathrm{SB}$, when the compost was humidified with water or mate tea. Similarly, E. coli did not grow in the aqueous extract of isolate UFV63 cultivated in sawdust enriched with $10 \% \mathrm{WB}+10 \% \mathrm{SB}$ when the compost was humidified with mate tea (Fig. 2). 

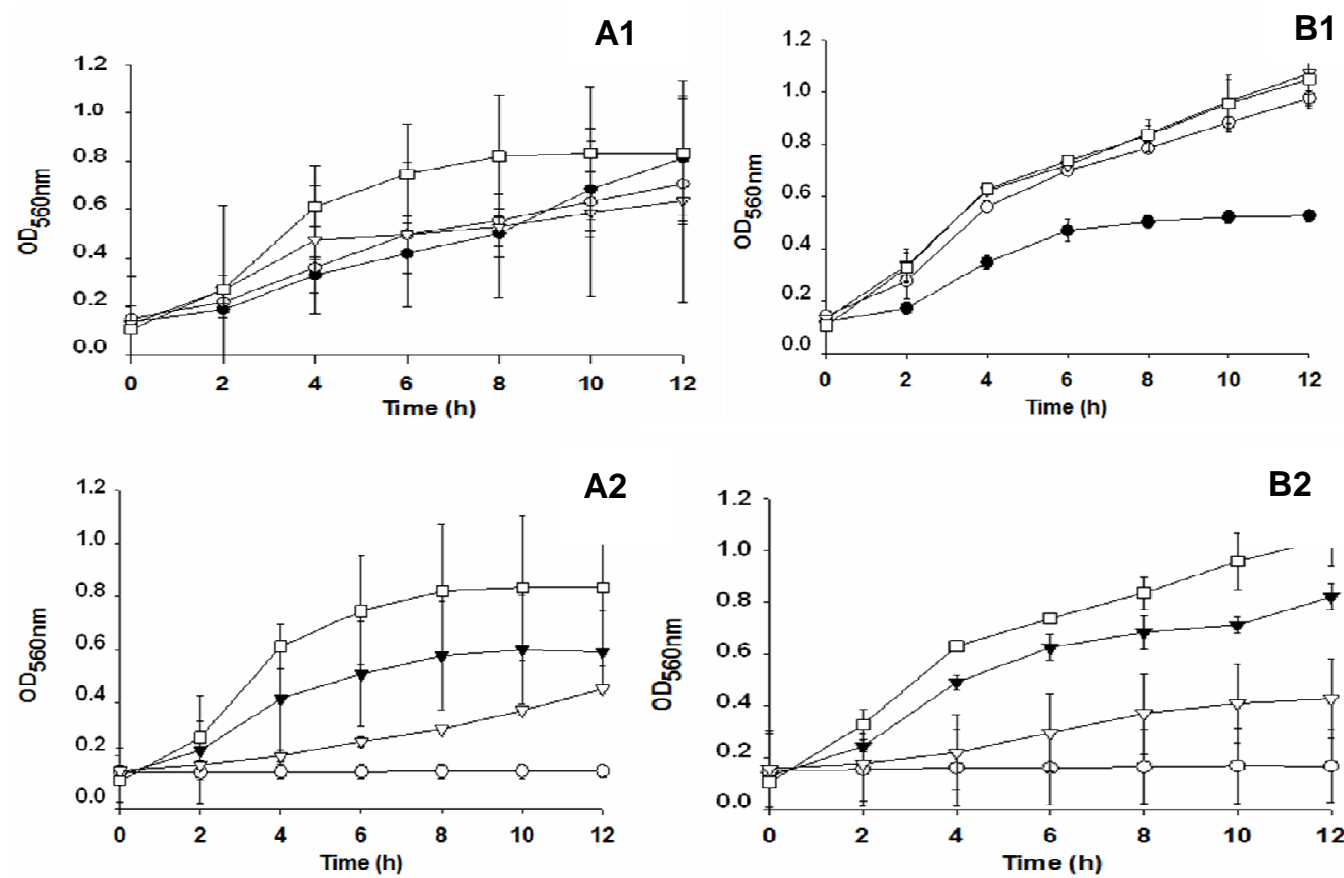

2

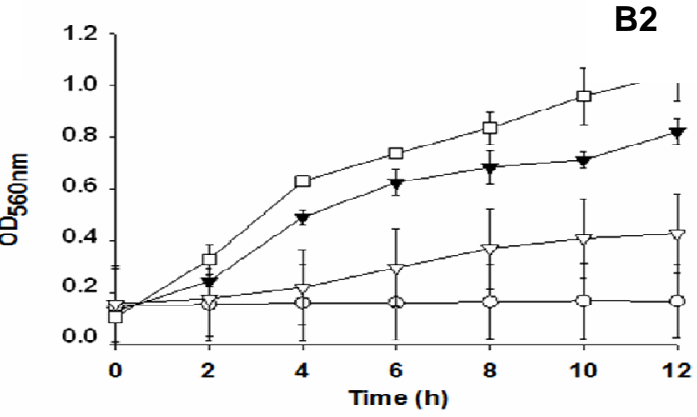

Figure 1 - Growth of Bacillus subtilis (A) and Escherichia coli (B) in BHI broth added of aqueous extract of shiitake mushroom, isolate UFV52, cultivated on sawdust-based substrates humidified with $0.1 \%$ mate tea extract (A1; B1) or water (A2; B2), and enriched with $20 \%$ rice $(\mathrm{RB})$, wheat $(\mathrm{WB})$, soybean $(\mathrm{SB})$ bran or combination of $10 \%$ of two of these

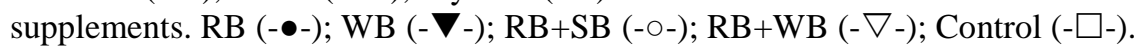
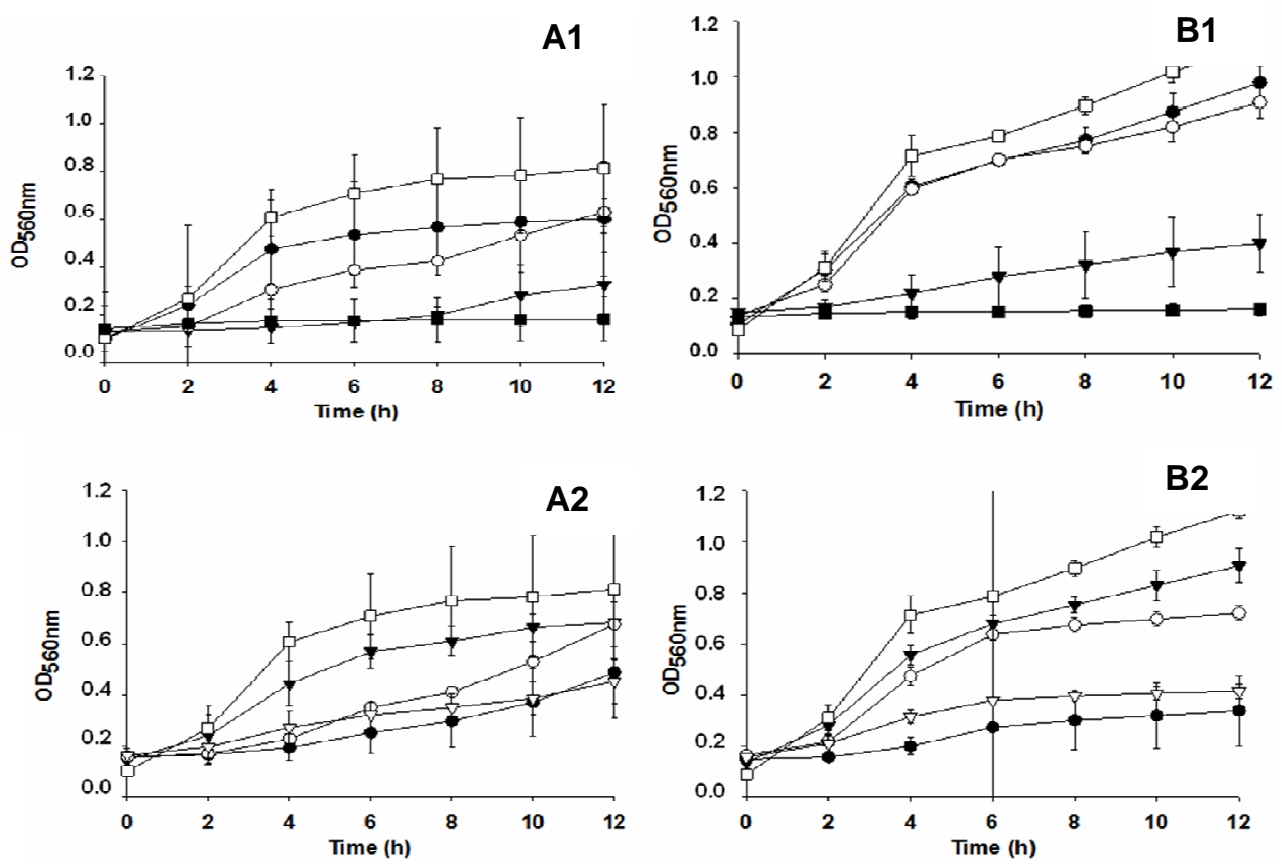

Figure 2- Growth of Bacillus subtilis (A) and Escherichia coli (B) in BHI broth added of aqueous extract of shiitake mushroom, isolate UFV63, cultivated on sawdust-based substrates humidified with $0.1 \%$ mate tea extract $(\mathrm{A} 1 ; \mathrm{B} 1)$ or water $(\mathrm{A} 2 ; \mathrm{B} 2)$, and enriched with $20 \%$ rice $(\mathrm{RB})$, wheat $(\mathrm{WB})$, soybean $(\mathrm{SB})$ bran or combination of $10 \%$ of two of these

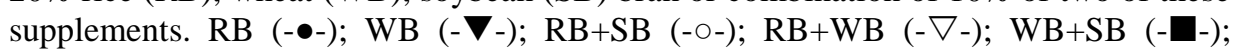
control (- $\square-)$. 
The water extracts from dried mushrooms of isolate UFV63 cultivated on sawdust-based substrate enriched with $20 \% \mathrm{WB}$ and humidified with water or $0.1 \%$ mate tea extract inhibited the growth of E. coli and B. subtilis (Fig. 3).

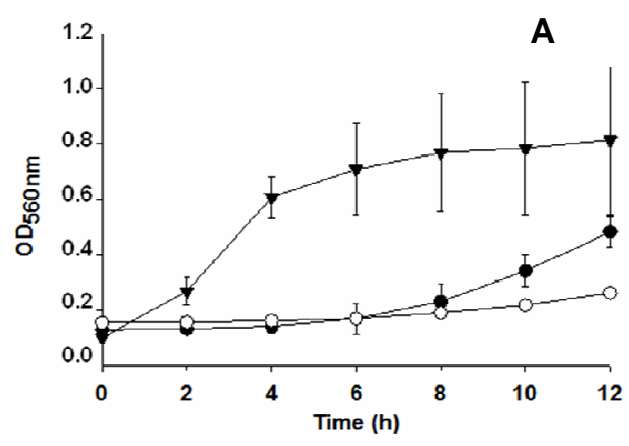

The antimicrobial activities of the isolates UFV52 and UFV63 were observed in the mushrooms produced on eucalyptus logs, but activity was not influenced by the growth stage of the mushroom (Fig. 4).

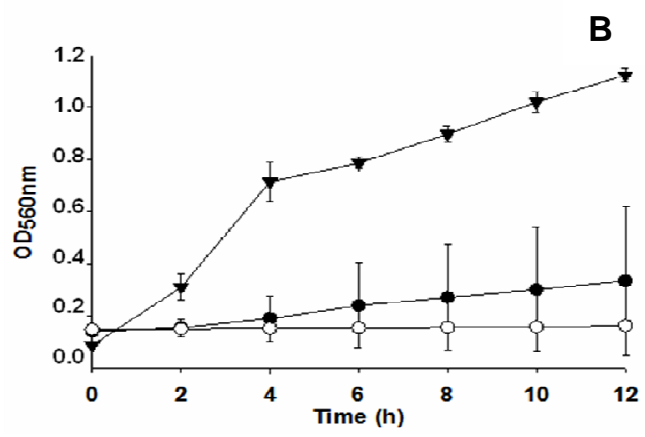

Figure 3 - Growth of Bacillus subtilis (A) and Escherichia coli (B) in BHI broth added of aqueous extract of dried shiitake mushroom, isolate UFV63, cultivated on sawdust-based substrates, enriched with wheat bran (WB), and humidified with $0.1 \%$ mate tea extract

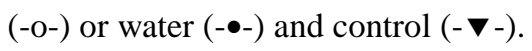
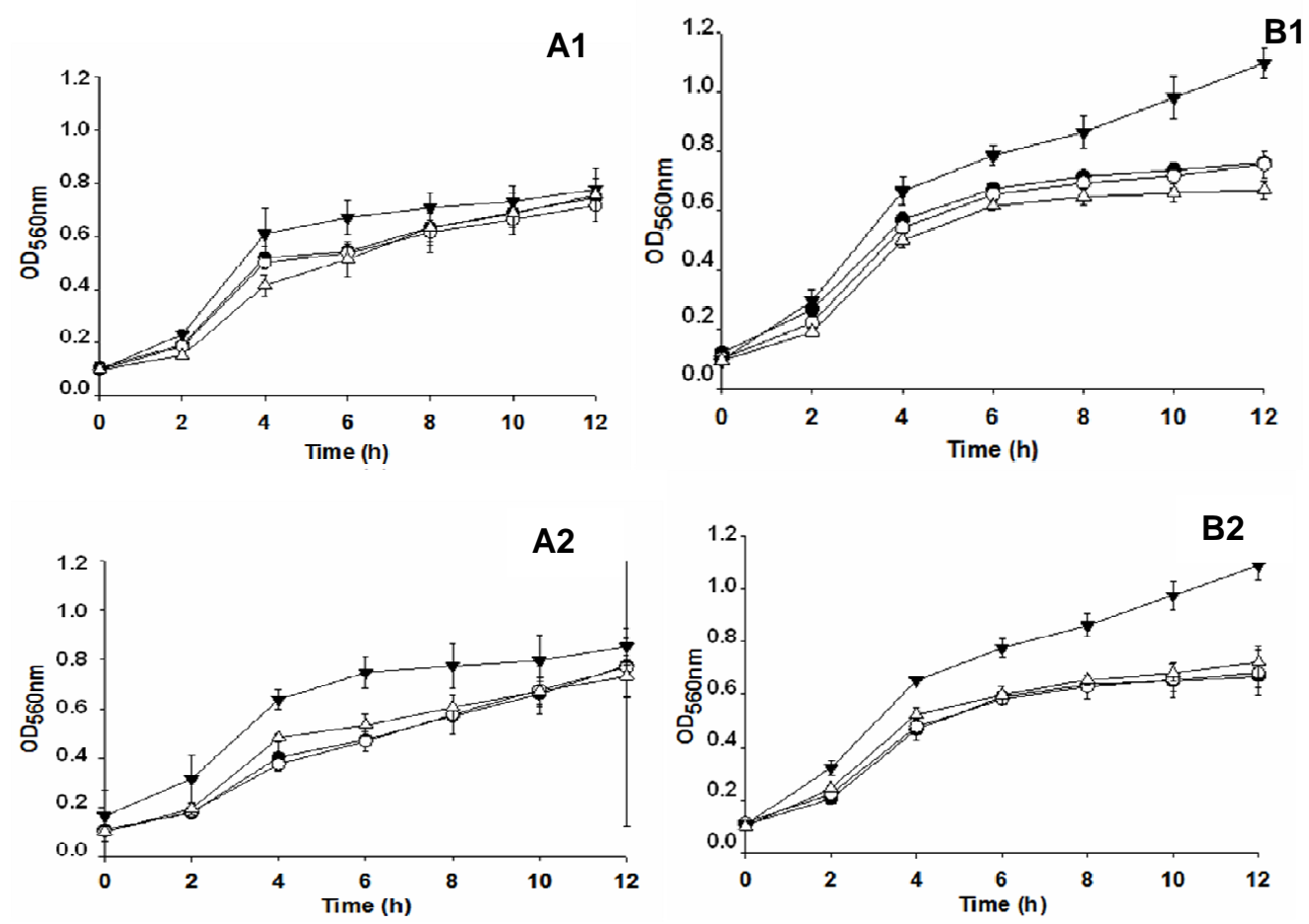

Figure 4 - Growth of Bacillus subtilis (A) and Escherichia coli (B) in BHI broth added of aqueous extract of fresh shiitake mushroom, isolates UFV52 (A1; B1) or UFV63 (A2; B2) cultivated on eucalyptus logs and collected in different growth stages of mushroom: 3

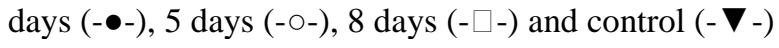

Aqueous extracts of fresh or dried mushrooms produced by isolates UFV52, UFV62 and UFV63 cultivated on eucalyptus logs collected on the fifth day after fructification induction inhibited $B$. subtilis as much as E. coli (Fig. 5). 

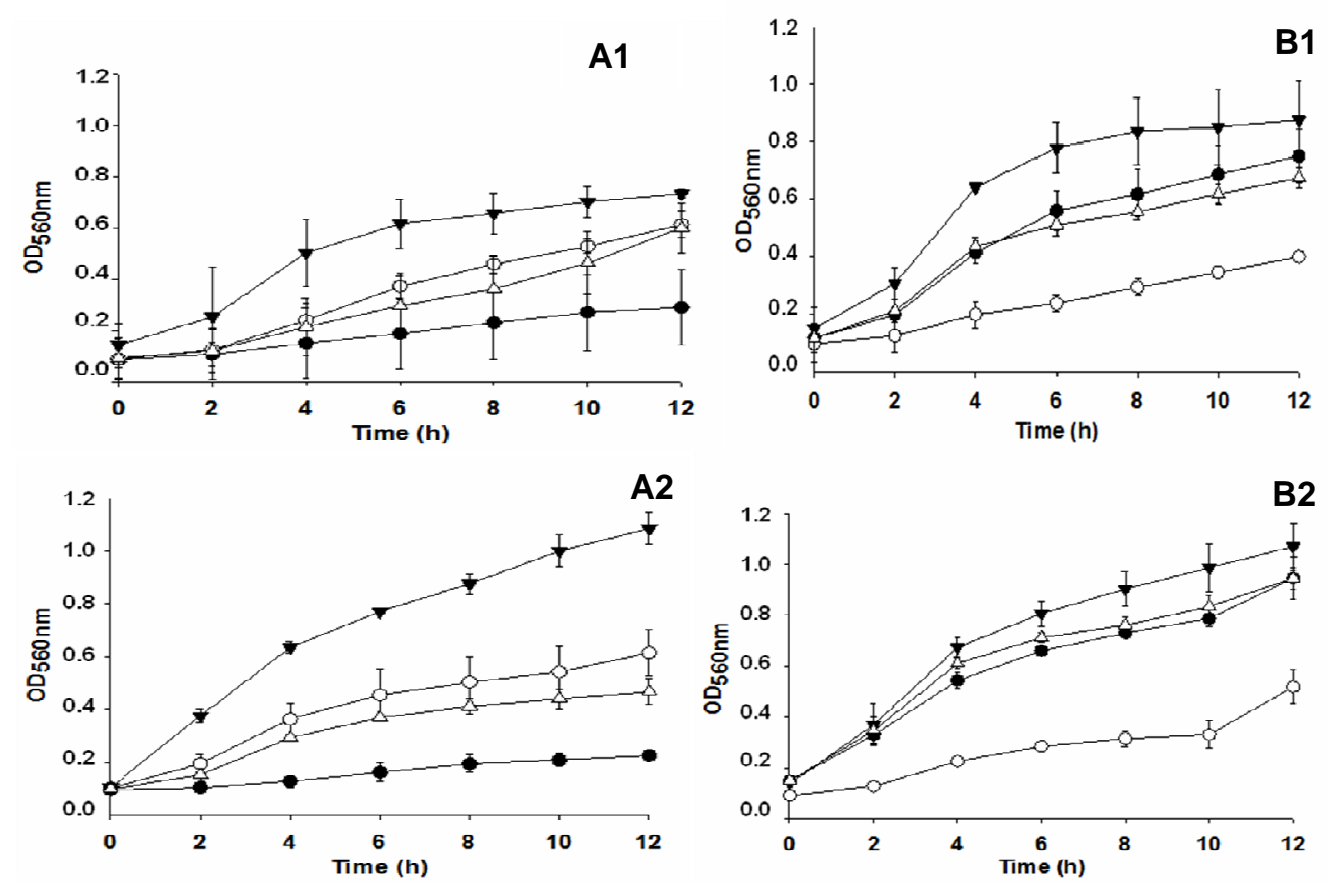

Figure 5 - Growth of Bacillus subtilis (A) and Escherichia coli (B) in BHI broth added of aqueous extract of shiitake mushrooms cultivated on eucalyptus logs, isolates UFV52 (-•-), UFV62 (-o-) or UFV63 (- $\square-)$, fresh (A1; B1) or dried (A2; B2), and control (- $\nabla$-).

\section{Nutrient concentrations in the shiitake} mushroom

The concentrations of $\mathrm{N}, \mathrm{K}, \mathrm{P}, \mathrm{Ca}$ and $\mathrm{Mg}$ in the dry material from the mushrooms varied according to the substrate on which the fungus was cultivated
(Tables 1 and 2). In general, the concentrations of the nutrients were higher when the fungi were cultivated on the sawdust-based substrates and enriched with grain bran rather than on eucalyptus logs (Table 4).

Table 4 - Concentration (mg/100 g) of N, P, K Ca and Mg in the shiitake mushroom cultivated on sawdust-based substrates (S) collected with five days and cultivated on eucalyptus logs (L) collected in different growth stages after fructification induction and extraction of antimicrobial substances.

\begin{tabular}{cccccc}
\hline Treatment & $\mathbf{N}$ & $\mathbf{P}$ & $\mathbf{K}$ & $\mathbf{C a}$ & $\mathbf{M g}$ \\
\hline S1 & $1103.68 \mathrm{~b}$ & $2285.75 \mathrm{~d}$ & $508.21 \mathrm{a}$ & $62.68 \mathrm{i}$ & $104.58 \mathrm{e}$ \\
S2 & $560.20 \mathrm{~b}$ & $2483.12 \mathrm{~d}$ & $601.01 \mathrm{a}$ & $148.39 \mathrm{~g}$ & $538.20 \mathrm{~d}$ \\
S3 & $2378.76 \mathrm{a}$ & $3822.49 \mathrm{a}$ & $979.59 \mathrm{a}$ & $194.91 \mathrm{e}$ & $495.86 \mathrm{~d}$ \\
S4 & $643.81 \mathrm{~b}$ & $2857.10 \mathrm{c}$ & $742.42 \mathrm{a}$ & $175.32 \mathrm{f}$ & $438.58 \mathrm{~d}$ \\
S5 & $2483.28 \mathrm{a}$ & $2023.83 \mathrm{e}$ & $686.45 \mathrm{a}$ & $165.53 \mathrm{f}$ & $422.39 \mathrm{~d}$ \\
S6 & $1103.68 \mathrm{~b}$ & $2964.75 \mathrm{c}$ & $773.36 \mathrm{a}$ & $175.32 \mathrm{f}$ & $361.37 \mathrm{~d}$ \\
S7 & $1605.35 \mathrm{a}$ & $2383.57 \mathrm{~d}$ & $830.07 \mathrm{a}$ & $474.07 \mathrm{~b}$ & $1238.65 \mathrm{~b}$ \\
S8 & $2295.15 \mathrm{a}$ & $2956.06 \mathrm{c}$ & $732.11 \mathrm{a}$ & $82.27 \mathrm{~h}$ & $980.26 \mathrm{c}$ \\
S9 & $1688.96 \mathrm{a}$ & $3108.74 \mathrm{~b}$ & $466.97 \mathrm{a}$ & $23.50 \mathrm{j}$ & $795.97 \mathrm{c}$ \\
S10 & $2274.25 \mathrm{a}$ & $3920.55 \mathrm{a}$ & $686.45 \mathrm{a}$ & $194.91 \mathrm{e}$ & $921.74 \mathrm{c}$ \\
S11 & $2357.86 \mathrm{a}$ & $3275.07 \mathrm{~b}$ & $689.39 \mathrm{a}$ & $3.92 \mathrm{k}$ & $404.96 \mathrm{~d}$ \\
S12 & $2023.41 \mathrm{a}$ & $2512.91 \mathrm{~d}$ & $758.63 \mathrm{a}$ & $82.27 \mathrm{~h}$ & $174.58 \mathrm{e}$ \\
S13 & $79.43 \mathrm{~b}$ & $2815.79 \mathrm{c}$ & $894.15 \mathrm{a}$ & $302.66 \mathrm{c}$ & $568.09 \mathrm{~d}$ \\
S14 & $1250.00 \mathrm{~b}$ & $1756.95 \mathrm{f}$ & $693.07 \mathrm{a}$ & $239.01 \mathrm{~d}$ & $237.47 \mathrm{e}$ \\
S15 & $1772.58 \mathrm{a}$ & $2321.75 \mathrm{~d}$ & $480.22 \mathrm{a}$ & $958.91 \mathrm{a}$ & $1624.06 \mathrm{a}$ \\
S16 & $2148.82 \mathrm{a}$ & $1499.75 \mathrm{~g}$ & $519.10 \mathrm{a}$ & $145.94 \mathrm{~g}$ & $249.30 \mathrm{e}$ \\
\hline C.V.(\%) & $\mathbf{2 7 . 1 3}$ & $\mathbf{3 . 2 2}$ & $\mathbf{1 8 . 1 2}$ & $\mathbf{3 . 8 1}$ & $\mathbf{1 2 . 4 8}$ \\
\hline
\end{tabular}




\begin{tabular}{|c|c|c|c|c|c|}
\hline Treatment & $\mathbf{N}$ & $\mathbf{P}$ & $\mathbf{K}$ & $\mathbf{C a}$ & Mg \\
\hline L1 & $1396.32 \mathrm{a}$ & $832.54 \mathrm{a}$ & $661.40 \mathrm{~b}$ & $57.79 a$ & $155.90 \mathrm{~d}$ \\
\hline L2 & $560.20 \mathrm{~b}$ & $785.99 b$ & $592.17 b$ & $3.92 \mathrm{a}$ & $28.89 \mathrm{e}$ \\
\hline L3 & $142.14 b$ & $624.01 \mathrm{c}$ & $256.31 b$ & $3.93 \mathrm{a}$ & $31.38 \mathrm{e}$ \\
\hline L4 & $2232.44 a$ & $772.34 b$ & $565.65 b$ & $3.95 \mathrm{a}$ & $404.96 c$ \\
\hline L5 & $204.85 b$ & $566.90 \mathrm{c}$ & $394.04 b$ & $123.90 \mathrm{a}$ & $134.74 d$ \\
\hline L6 & $560.20 \mathrm{~b}$ & $761.42 b$ & $504.23 b$ & $766.44 a$ & $31.75 \mathrm{e}$ \\
\hline L7 & $455.68 b$ & $831.06 \mathrm{a}$ & $500.25 b$ & $10.77 \mathrm{a}$ & $60.39 \mathrm{e}$ \\
\hline L8 & $121.24 b$ & $730.01 b$ & $473.74 b$ & $101.86 a$ & $93.89 \mathrm{~d}$ \\
\hline L9 & $1751.67 \mathrm{a}$ & $874.50 \mathrm{a}$ & $565.65 b$ & $113.62 \mathrm{a}$ & $383.29 c$ \\
\hline L10 & $737.87 \mathrm{~b}$ & $721.82 b$ & $465.78 b$ & $33.30 \mathrm{a}$ & $130.88 \mathrm{~d}$ \\
\hline L11 & $1082.77 \mathrm{a}$ & $771.85 b$ & $500.25 b$ & $213.03 a$ & $542.68 b$ \\
\hline L12 & $367.56 \mathrm{~b}$ & $860.47 \mathrm{a}$ & $567.13 b$ & $167.98 \mathrm{a}$ & $355.77 \mathrm{c}$ \\
\hline L13 & $1103.68 \mathrm{a}$ & $918.82 \mathrm{a}$ & $1453.92 \mathrm{a}$ & $263.48 \mathrm{a}$ & $1516.971 \mathrm{a}$ \\
\hline L14 & $602.01 \mathrm{~b}$ & $947.37 \mathrm{a}$ & $1473.06 \mathrm{a}$ & $38.20 \mathrm{a}$ & 102.3601 \\
\hline
\end{tabular}

$\begin{array}{llllll}\text { C.V. }(\%) & 53.99 & 5.61 & 12.17 & \mathbf{2 0 9 . 7 0} & \mathbf{7 . 4 2}\end{array}$

$\mathrm{CV}=$ Coefficient of Variation. Number followed by the same letter in the same column, do not differ by Scott Knott test $(\mathrm{P}<0.05)$.

(cont. table4)

\section{DISCUSSION}

\section{Mushroom production}

The effect of enrichment of sawdust with the agricultural waste such as cereal bran on the cultivation of mushroom has been the subject of several studies. These works aimed to enhance the substrate with low-cost nutrients and to reduce the waste, thereby minimizing the pollution, and generating the products of commercial interest. Poor mycelial growth on the substrates enriched with SB could be attributed to the absence of one or more nutritional compounds in the soybean bran required for the fungal growth, or to the presence of substance that inhibited the fungal growth.

Low fructification by the isolate UFV11 (Table 3) could be result of maintaining this fungus under the laboratory conditions. Mycelial transference over long periods of time can cause physiological and/ or morphological changes in the fungus (Maekawa et al., 1988). The isolates UFV52 and UFV63 were recently re-isolated from the basidiocarps, and this practice should guarantee fructification properties. It could be concluded that the vegetative mycelial growth on a sawdust-based medium was clearly dependent on the isolate. Ohga (1992) reported that the incubation time, tree species of the sawdust, concentration and composition of the nutritional supplements, water content, rate of gas exchange, and the isolate significantly influenced the mushrooms production.

Vegetative mycelial growth on natural logs may occur from 6 to 18 months, depending on the tree species, log size, spawn cultivar, moisture content and temperature of the environment, isolate, and other variables (Royse, 2001). This suggests that more investigation of the isolates with precocious fructification on logs is necessary with the aim of reducing cultivation time. Evaluation of these characteristics is important in the selection process of isolates to meet consumer needs and increase the commercial value.

\section{Antimicrobial activity of the aqueous extract}

The shiitake mushrooms had antimicrobial activities against the Gram-positive and Gramnegative bacteria (Fig. 1 and 2) as previously described by others authors (Komemushi et al., 1995, Venturini et al, 2008). However, Hirasawa et al. (1999) observed that bacteria of the genera Escherichia ssp., Bacillus ssp., Enterococcus ssp. and Staphylococcus ssp. were not inhibited by the antimicrobial substances from the dried shiitake mushrooms soluble in chloroform, ethyl acetate, or water. The antimicrobial activity of the mycelial extract of L. edodes, Le1 was observed against the Gram-positive bacteria using overlay methods, but not against the Gram-negative bacteria. The Le1 isolate presented activity against eight species out of 20 food borne pathogens and food contaminants, mainly against the Gram-positive bacteria. B. subtilis was the most sensitive (Ishikawa et al., 2001).

Rice bran (Fig. 3) has also been tested by Hassegawa et al. (2005) in liquid culture media 
which resulted in higher antimicrobial activity for mycelial cultures of $L$. edodes. Results observed in this study showed that the production of antimicrobial substance(s) by $L$. edodes was dependent on the isolate (Fig. 4 and 5). Ishikawa et al. (2001) showed that the antibacterial activity in the mycelial extract against $B$. subtilis varied considerably among the 35 isolates of $L$. edodes. Similar results were observed by Tsuneda and Thorn (1994), who evaluated the production of antimicrobial substance(s) by four isolates of $L$. edodes against seven isolates of Pseudomonas species. Differences in the inhibitory activity among these isolates (Fig. 4 and 5) could be attributed to the presence of at least one substance with antimicrobial activity. This showed that the presence of substances with antimicrobial activity in fresh mushrooms could increase the shelf life of the mushrooms and those substances, or even dried mushroom in the powder form could be used to preserve the food.

\section{Micronutrient concentrations in shiitake mushrooms}

In the substrates enriched with cereal bran, nutrients are available in higher quantities than in logs, facilitating absorption (Table 4). Mushrooms are a good source of minerals. Minerals can be taken by the mycelia from the substrate and translocated to fruit bodies (Chang and Miles, 1989).

In Brazil, according to the Ordinance $\mathrm{N}^{0} 27$ of Ministry of Health, for food to be considered a source of a mineral, the mineral must be present and comprise at least 15\% of Recommended Dietary Allowances - (RDA) (Sturion and de Camargo Ranzani). Considering the RDA of phosphorus as $800 \mathrm{mg} / 100 \mathrm{~g}$, mushrooms that were rich in $\mathrm{P}$ were primarily those cultivated on the sawdust-based substrates (Table 4). Phosphorus is the second most abundant mineral in shiitake mushrooms, and values between 302 $\mathrm{mg} / 100 \mathrm{~g}$ (Mizuno, 1994) and $408 \mathrm{mg} / 100 \mathrm{~g}$ (Longvah and Deosthale, 1998) have been reported. Among other nutrients, nitrogen presented the highest concentrations, with the values between 79 to $2483 \mathrm{mg} / 100 \mathrm{~g}$ (Table 4). Manzi et al. (1999) reported lower values, with $0.35 \mathrm{mg} / 100 \mathrm{~g}$ in fresh mushrooms and 3.47 $\mathrm{mg} / 100 \mathrm{~g}$ in dried mushrooms. The results observed here classified the shiitake mushrooms as a source of $\mathrm{K}$, considering the RDA for this element as $2000 \mathrm{mg} / 100 \mathrm{~g}$ (RDA, 1989). The values obtained in the present work were higher than $300 \mathrm{mg} / 100 \mathrm{~g}$. An important observation was that the samples of mushroom used for mineral evaluation were first subjected to the extraction of antimicrobial substances.

Apparently some potassium might have been extracted. This could be verified by comparing the values of this element with those in L13 and L14, which were not submitted to extraction and which presented potassium concentrations higher than $1400 \mathrm{mg} / 100 \mathrm{~g}$ (Table 4). Potassium concentrations of $2647.5 \mathrm{mg} / 100 \mathrm{~g}$ have been observed (Manzi et al., 1999).

Concentrations of $\mathrm{Mg}$ and $\mathrm{Ca}$ were variable (Table 4 ), and were ten times higher than what has been reported in the literature, from $116.5 \mathrm{mg} / 100 \mathrm{~g}$ (Manzi et al., 1999) to $227 \mathrm{mg} / 100 \mathrm{~g}$ (Longvah and Deosthale, 1998) for $\mathrm{Mg}$, and from $13 \mathrm{mg} / 100$ $\mathrm{g}$ (Mizuno, 1994) to $188 \mathrm{mg} / 100 \mathrm{~g}$ (Longvah and Deosthale, 1998) for Ca. The RDA of $\mathrm{Mg}$ is 270 to $300 \mathrm{mg}$ (RDA, 1989), suggesting that shiitake mushrooms are rich in this mineral.

It could be concluded that in addition to the fungal isolate, the growth substrate must be considered when evaluating the minerals or the production of antimicrobial substance(s) in the mushrooms. Considering that shiitake mushroom are a food rich in minerals and contain many other substances that could be used to aid in the food preservation, their cultivation and use must be promoted, especially in the countries that do not often use mushrooms in their cuisines.

\section{ACKNOWLEDGEMENTS}

The authors are grateful for the scholarship received from CNPq. This result is part of the project financed by $\mathrm{CNPq} 520968 / 01-8$ and 50.7517/2004-0

\section{REFERENCES}

Bew, R. E.; Chapman, J. R.; Jones, R. H.; Lowe, B. E.; Lowe, G. (1966), Natural acetylenes part XVIII. Some allenics polyacetylenes from basidyomicetes. $J$. Chem. Soc., 129-135.

Braga, J. M; Defilipo, B.V. (1974), Determinação espectrofotométrica de fósforo em extratos de solo e material vegetal. Rev. Ceres, 21, 73-85. 
Campbell, A.C; Racjan, M. (1999), The commercial exploitation of the white rot fungus Lentinula edodes (shiitake). Int. Biodeter. Biodegr., 43, 101-107.

Cataldo, D.A; Schrader, L.E.; Young, V.L. (1974), Analysis by digestion and colorimetric assay of total nitrogen in plant tissues high in nitrate. Crop Sci., 14, 854-856.

Chang, S. T. (1999), Global impact of edible and medicinal mushrooms on human welfare in the $21^{\text {st }}$ century: nongreen revolution. Int. J. Med. Mushrooms, 1, p.4.

Chang, S.T.; Miles, P.G. The nutritional attributes and medicinal value of edible mushrooms. In: Chang, ST; Miles, PG, (1989), editors. Edible mushrooms and cultivation. Boca Raton: CRC Press Inc., 27-38.

Chihara, G., Maeda, Y. Y., Hamuro, J., Sasaki, T.; Fukuoka, F. (1969), Inhibition of mouse sarcoma 180 by polysaccharides from Lentinus edodes (Berk.) Sing. Nature, 222, 687-688.

Enman, J; Hodge, D; Berglund, K.A et al. (2008), Production of the bioactive compound eritadenine by submerged cultivation of Shiitake (Lentinus edodes) mycelia. J. Agric. Food Chem. 56, 2609-2612.

Fujii, T., Maeda, H., Susuki, H.; Ishida, N. (1978), Isolation and characterization of a new antitumor polysaccharide, KS-2, extracted from culture mycelia of Lentinus edodes. J. Antibiot., 31, 1079-1090.

Hassegawa, R.H.; Kasuya, M.C.M.; Vanetti, M.C.D. (2005), Growth and antibacterial activity of Lentinula edodes in liquid media supplemented with agricultural wastes. Electron. J. Biotech., 8, 212-215.

Hatvani, N. (2001), Antibacterial effect of the culture fluid of Lentinus edodes mycelium grown in submerge liquid culture. Int. J. Antimicrob. Agents, 17, 71-74.

Hatvani, N.; Mécs, I. (2001), Production of laccase and manganese peroxidase by Lentinus edodes on maltcontaining by-product of the brewing process. Process Biochem., 37, 491-496.

Hatvani, N.; Mécs, I. (2002), Effect of the nutrient composition on dye decolorisation and extracellular enzyme production by Lentinus edodes on solid medium. Enzyme Microb. Tech., 30, 381-386.

Hirasawa, M; Shouji, N; Neta, T. et al. (1999), Three kinds of antibacterial substances from Lentinus edodes (Berk.) Sing. (Shiitake, an edible mushroom). Int. J. Antimicrob. Agents, 11, 151-157.

Ishikawa, N.K.; Kasuya, M.C.M.; Vanetti, M.C.D. (2001), Antibacterial activity of Lentinula edodes grown in liquid medium. Braz. J. Microbiol., 32, 206210.

Kitzberger, C.S.G; Smania, A.; Pedrosa, R.C. et al. (2007). Antioxidant and antimicrobial activities of shiitake (Lentinula edodes) extracts obtained by organic solvents and supercritical fluids. J. Food Eng., 80, 631- 638.
Kobayashi, N., Hiramatsu, A. Akasuka, T. (1987), Purification and chemical properties of an inhibitor of plant virus infection from fruting bodies of Lentinus edodes. Agric. Biol. Chem., 15, 883-890.

Komemushi, S., Yamamoto, Y., Fujita. T. (1996), Purification and identification of antimicrobial substances produced by Lentinus edodes. J. Antibact. Antifung. Agents, 24, 21-25.

Komemushi, S; Yamamoto, Y.; Fujita, T. (1995), Antimicrobial substance produced by Lentinus edodes. J. Antibact. Antifung. Agents, 23, 81-86.

Longvah, T; Deosthale, Y.G. (1998), Compositional and nutritional studies on edible wild mushroom from northeast India. Food Chem., 63, 331-334.

Maeda, Y.Y; Takahama, S.; Yonekawa, H. (1998), Four dominant loci for the vascular responses by the antitumor polysaccharide, lentinan. Immunogenetics, 47, 159-165.

Maekawa, N; Fukuda, M; Arita, I. And Komatsu, M. (1988), Cryopreservation of the basidiomycetous fungi in liquid nitrogen. Rept. Tottori Mycol. Inst., 26, 15-28.

Makkar, R.S.; Tsuneda, A; Tokuyasu, K. et al. (2001), Lentinula edodes produces a multicomponent protein complex containing manganese (II)-dependent peroxidase, laccase and beta-glucosidase. FEMS Microbiol Lett, 200, 175-179.

Manzi, P; Gambelli, L; Marconi, S et al. (1999), Nutrients in edible mushrooms: an inter-species comparative study. Food Chem., 65, 477-482.

Mata, G; Savoie, J.M. (1998), Extracellular enzyme activities in six Lentinula edodes strains during cultivation in wheat straw. W. J. Microb. Biot., 14, 513-519.

Minato, K; Mizuno, M; Terai, H. et al.(1999), Autolysis of lentinan, an antitumor polysaccharide, during storage of Lentinus edodes, shiitake mushroom. J. Agr. Food Chem., 47, 1530-1532.

Mizuno, T. (1994), Five grams a day: if you drink this mushroom you don't afraid cancer. Tokyo:Japão, Shinano Press., 172p (in japonese).

Nagai, M; Kawata, M; Watanabe, H. et al. (2003), Important role of fungal intracellular laccase for melanin synthesis: purification and characterization of an intracellular laccase from Lentinula edodes fruit bodies. Microbiology-SGM, 149, 2455-2462.

Nagai, M; Sato, T; Watanabe, H. et al. (2002), Purification and characterization of an extracellular laccase from the edible mushroom Lentinula edodes, and decolorization of chemically different dyes. Appl. Microbiol. Biot., 60, 327-335.

Ngai, Phk; Ng, Tb. (2003), Lentin, a novel and potent antifungal protein from shitake mushroom with inhibitory effects on activity of human immunodeficiency virus-1 reverse transcriptase and proliferation of leukemia cells. Life Sci., 73, 33633374. 
Ohga, S. (1992), Adaptability of Lentinus edodes strains to a sawdust-based cultivating procudere. Mokuzai Gakkaishi, 38, 301-309.

Ohga, S.; Royse, D.J. (2001), Transcriptional regulation of laccase and cellulase genes during growth and fruiting of Lentinula edodes on supplemented sawdust. FEMS Microbiol Lett, , 201, 111-115.

Pacumbaba, R.P.; Beyl, C.A.; Pacumbaba, R.O. (1999), Shiitake mycelial leachate supresses growth of some bacterial species and symptoms of bacterial wilt of tomato and lima bean in vitro. Plant Dis., 83, 20-23.

Pascholati, S.F.; Stangarlin, J.R.; Piccinin, E. (1998), Cogumelos: cultivo e comercialização (shiitake $e$ cogumelo do sol). Cuiabá: SEBRAE/MT, 85p. (coleção agroindústria, v.17).

Przbylowicz, P.; Donoghue, J. (1990), Shiitake growers handbook - the art and science of mushroom cultivation. New York: Kendall/Hunt Publishing Company, 217p.

Recommended Dietary Allowances. (1989), $10^{\text {th }}$ Edition. Washington:National Press.

Regina, M; Broetto, F; Giovannozzi-Sermanni, G; Marabotini, R; Peranni, C. (2008). Influence of stationary and bioreactor cultivation on Lentinula edodes (Berk) Pegler lignocellulolitic activity. Braz. Arch. Biol. Technol., 51, 223-233.

Royse, D.J. (2001), Cultivation of Shiitake on Synthetic and Natural Logs. College of Agricultural Sciences, Cooperative Extension, Pennsylvania State University, University Park, PA, USA, 12p.

Royse, D.J.; Sanchez, J.E. (2007), Ground wheat straw as a substitute for portions of oak wood chips used in shiitake (Lentinula edodes) substrate formulae. Bioresource Technol., 98, 2137-2141.

Sasaki, S.H.; Linhares, R.E.C.; Nozawa, C.M. et al. (2001), Strains of Lentinula edodes suppress growth of phytopathogenic fungi and inhibit Alagoas serotype of vesicular stomatitis virus. Braz. J. Microbiol., 32, 52-55.

Savoie, J.M; Mata, G.; Billete, C. (1998), Extracellular laccase production during hyphal interactions between Trichoderma sp. and shiitake, Lentinula edodes. Appl. Microbiol. Biot., 49, 589-593.

Shimada, Y; Morita, T; Sugiyama, K. (2003), Dietary eritadenine and ethanolamine depress fatty acid desaturase activities by increasing liver microsomal phosphatidylethanolamine in rats. J. Nutr., 133, 758765 a.
Shimada, Y; Morita, T; Sugiyama, K. (2003), Eritadenine-induced alterations of plasma lipoprotein lipid concentrations and phosphatidylcholine molecular species profile in rats fed cholesterol-free and cholesterol-enriched diets. Biosci. Biotech. Bioch., 67, 996-1006b.

Silva, E.M.; Martins, S.F.; Milagres, A.M.F. (2008), Extraction of manganese peroxidase produced by Lentinula edodes. Bioresource Technol, 99, 24712475.

Silva, E.M; Machuca, A.; Milagres, A.M.F. (2005), Evaluating the growth and enzyme production from Lentinula edodes strains. Process Biochem, 40, 161164.

Sturion, G.L.; de Camargo Ranzani, M.R. (2000), Mineral composition of edible mushrooms cultivated in Brazil - Pleurotus spp and other dehydrated species. Arch. Latinoam. Nutr., 50, 102-108.

Tedesco, M.J.; Gianello, C; Bissani, C.A.; Bohnen, H; Volkweis, S.J. (1995), Análises de solo, plantas e outros materiais. $2^{\mathrm{a}}$ ed. Porto Alegre, Departamento de Solos, UFRGS, 174p.

Tokimoto, K., Fujita, T., Takaishi, Y. (1987), Increased or induced formation of antifungal substance in cultures of Lentinus edodes by the attack of Trichoderma ssp. Proc. Japan Acad. Series B. Phys. and Biol. Sciences, 63, 277-280.

Tsuneda, A.; Thorn, G. (1994), Interactions between Lentinula edodes and pseudomonas. Can. J. Microbiol., 40, 937-943.

Venturini, M.E., Rivera, C.S., Gonzalez, C. (2008), Antimicrobial activity of extracts of edible wild and cultivated mushrooms against foodborne bacterial strains. J.Food Protect., 71, 1701-1706.

Vetter, J. (1994), Data on arsenic and cadmium contents of some common mushrooms. Toxicon., 32, 11-15.

Wasser, S.P.; Weis, A.L. (1999), Medicinal properties of substances occurring in higher basidiomycetes mushrooms: current perspectives (Review). Int. J. Med. Mushrooms, 1, 31-62.

Yang, B.K., Kim, D.H., Jeong, S.C. et al. (2002), Hypoglycemic effect of a Lentinus edodes exopolymer produced from a submerged mycelial culture. Biosci. Biotech. Bioch, 66, 937-942.

Received: March 30, 2010; Revised: July 01, 2010; Accepted: July 11, 2011. 